[Vol. 129:882

\title{
GOMMENTS
}

\section{THE EFFECT OF ASSET TRANSFERS ON MEDICAID ELIGIBILITY}

Julia Fabula is a seventy-four year-old woman whose monthly. income is $\$ 266$. She requires nursing home care costing between $\$ 700$ and $\$ 1000$ for each month. Shortly after giving her house to relatives, Ms. Fabula applied for state assistance to meet the costs of her medical care. Despite this gratuitous transfer of a resource that could have been liquidated to help pay for her care, she is eligible for medical assistance benefits. Ms. Fabula lives in Maryland. ${ }^{1}$

Enosinsio Manahan is a senile, eighty-five year-old man who has been living in a nursing home since January 1977. He is expected to require institutional care indefinitely. In May 1977, his wife sold her house to pay off various debts; Mr. Manahan had a community property interest in the house. Early in 1978, he applied for state assistance in meeting the costs of his medical care. Despite a finding by a state hearing officer that Mr. Manahan " 'lacked a capacity to transact legal business," " 2 a statutory presumption that he transferred the property in order to qualify for state subsidization of his nursing home care makes him ineligible for state assistance. ${ }^{3}$ Mr. Manahan lives in California. ${ }^{4}$

Ms. Fabula and Mr. Manahan are "medically indigent" or "medically needy" individuals. Medical indigence differs from poverty; a medically indigent person has sufficient income and other resources to meet his or her daily living expenses, but lacks the funds to pay for necessary medical care. ${ }^{5}$

Congress recognized the concept of medical indigence in 1965 when it established the cooperative federal-state Medicaid program

1 Fabula v. Buck, 598 F.2d 869, 871-74 (4th Cir. 1979).

2 Brief for Appellants at 8, Dawson v. Myers, 622 F.2d 1304 (9th Cir.), cert. granted sub nom. Beltran v. Myers, $101 \mathrm{~S}$. Ct. 353 (1980). The Court heard oral argument in this case on March 24, 1981. 49 U.S.L.W. 3683.

3 Id. 9.

4 See Dawson v. Myers, 622 F.2d 1304 (9th Cir.) (upholding the state's denial of benefits), cert. denied sub nom. Beltran v. Myers, 101 S. Ct. 353 (1980).

6 For example, the "working poor" who cannot afford health insurance are often included in this group. See Naliboff \& Lang, Expanding Access to Health Care: Written Eligibility Standards for the Medically Indigent, 13 CLEARINGrouse REv. 848, 848-49 (1980). Throughout this Comment, the terms "medically needy" and "medically indigent" will be used interchangeably. 
to assist the poor in meeting the cost of health care. ${ }^{8}$ States choosing to participate in the Medicaid program have the option of providing Medicaid benefits to the medically needy. ${ }^{\top}$ Several states with such programs, however, deny Medicaid to applicants who dispose of assets before application for benefits. ${ }^{8}$ In addition, some state laws have provided for termination of Medicaid benefits to recipients who transfer assets to prevent the state's recovering the cost of medical assistance from the recipient's estate after his death. ${ }^{9}$ Although few cases have been decided in this area, the trend in the federal courts and in some state courts has been to invalidate these "transfer of assets" rules by holding that they conflict with federal law.10 Recently, however, the Ninth Circuit Court of Appeals halted this trend by upholding California's transfer of assets rule in Dawson v. Myers. ${ }^{11}$

The courts' resolutions of the asset transfer issue have been unsatisfactory. Construing the same statutory and regulatory language, they have reached the disparate results illustrated by the cases of Ms. Fabula and Mr. Manahan. Other courts have manipulated the statutory and regulatory language to reach results that

6 Social Security Amendments of 1965, Pub. I. No. 89-97, 79 Stat. 286 (codified in scattered sections of $26,42,45$ U.S.C.). See S. REP. No. 404, 89th Cong., Ist Sess. 9, reprinted in [1965] U.S. CODE CONG. \& AD. News 1943, 1950; Naliboff \& Lang, supra note 5 , at 849 \& n.8.

The federal government's share of the cost of Medicaid benefits is based on the state's per capita income and ranges from $50 \%$ to $83 \%$. 42 U.S.C. $\$ 1396 \mathrm{~d}$ (b) (1976). infra.

742 U.S.C. $\$ 1396 \mathrm{a}(\mathrm{a})(10)(\mathrm{C})(\mathrm{i})(1976)$. See text accompanying notes $17-29$

8 See, e.g., Car. Wexf. \& Inst. Code $\$ 14015$ (West 1980); Mass. ANn. Laws ch. 118E, 13 (Michie/Law. Co-op 1975); Pa. STat. AnN. tit. 62, 441.2 (Purdon Supp. 1980-81).

o E.g., N.Y. Soc. SERv. Law $\$ 366(1)(e)$ (McKinney Supp. 1980). The New York law would deny eligibility even if the transferred asset is one that would not affect eligibility if the applicant or recipient retained it (for example, the applicant's home) on the theory that the transfer was made to prevent the state from recovering the cost of benefits after the recipient's death. See also Fabula v. Buck, in which the court invalidated a Maryland regulation making ineligible for Medicaid any applicant or recipient who transferred assets in order to circumvent the state's recovery procedures. 598 F.2d 869, 871 (4th Cir. 1979).

Federal law places some limitations on a state's recovery from a recipient's estate. States may recover only for benefits supplied to a recipient aged sixty-five or older. Moreover, states may not recover so long as the recipient's spouse or disabled or minor child is still living. 42 U.S.C. $\$ 1396 a(a)(18)(1976)$.

${ }^{10}$ See, e.g., Caldwell v. Blum, 621 F.2d 491 (2d Cir. 1980), petition for cert. filed, 49 U.S.L.W. 3005 (U.S. June 24, 1980) (No. 79-2034); Fabula v. Buck, 598 F.2d 869 (4th Cir. 1979); Scarpuzza v. Blum, 73 A.D.2d 237, 426 N.Y.S.2d 505 (1980).

11622 F.2d 1304 (9th Cir.), cest. granted sub nom. Beltran v. Myers, 101 S. Ct. $353(1980)$. See text accompanying notes $45-52$ infra. Accord, Lerner v. Department of Health and Social Servs., 70 Wis. 2d 670, 235 N.W.2d 478 (1975). 
seemed just in the cases before them. ${ }^{12}$ Recent federal legislation ${ }^{13}$ is equally unsatisfactory because it fails to resolve the conflict illustrated by the cases and thus paves the way for continuing piecemeal solutions. ${ }^{14}$

This Comment focuses on the application of state transfer of assets rules to the elderly medically indigent..$^{15}$ Part $I$, in presenting the origins and significance of the asset transfer problems, argues that the states need a method of protecting against abusive asset transfers because their alternative may be to restrict or eliminate essential care for the medically needy. The major asset transfer cases, which pose the basic questions in this area, are discussed in part II. After proposing in part III a reinterpretation of the federal statute and regulations at issue in these cases, part IV critically examines federal legislation recently enacted to deal with the asset transfer problem. The Comment concludes that, because the recent legislation permits states to create their own asset transfer policies, but within poorly defined limits, the issue is not yet resolved. The states must recognize the problems highlighted by the cases and establish asset transfer policies that strike a reasonable balance between the needs of Medicaid recipients and the states' concern for providing benefits to the needy.

\section{The Asset Transfer Issue}

\section{A. Origins}

States choosing to participate in the Medicaid program ${ }^{16}$ must provide benefits to the "categorically needy," those individuals who

12 See notes 102-10 infra \& accompanying text.

13 Social Security Amendments of 1980, Pub. L. No. 96-611, $§ 5,94$ Stat. 3567 (to be codified in 42 U.S.C. $\$ 1382 b, 1396 a$ ).

14 See text accompanying notes 145-77 infra.

15 Most of the cases in the area involve elderly applicants. See, e.g., Fabula v. Buck, 598 F.2d 869 (4th Cir. 1979); Scarpuzza v. Blum, 73 A.D.2d 237, 426 N.Y.S.2d 505 (1980); Lerner v. Department of Health and Social Servs., 70 Wis. 2d 670, 235 N.W.2d 478 (1975). Elderly people also are more likely to become permanent residents of long-term care facilities, see text accompanying notes 37-39 infra, and they may wish to transfer their homes (and other assets) to relatives to avoid probate. See Brief for Appellants at 6-7, Dawson v. Myers (profile of plaintiff Dawson who quitclaimed her interest in her home to her grandchildren because she wanted them to enjoy their "inheritance" before her death).

This Comment does not discuss Medicare, the national health insurance program for the elderly, which covers long-term care only for a limited period of time and only after hospitalization. See Note, Medicare and Medicaid: The Failure of the Present Health Care System for the Elderly, 17 Arux. L. REv. 522, 523-26 (1975). The elderly person who needs government assistance to meet the costs of indefinite or permanent care cannot rely on Medicare.

16 See note 6 supra \& accompanying text. 
receive cash payments from the federal or a state government to cover daily expenses because their incomes and other resources are insufficient. ${ }^{17}$ At their option, participating states also may provide Medicaid benefits to the "medically needy," 18 defined by the Department of Health and Human Services (HHS) ${ }^{10}$ as "aged, blind, or disabled individuals or families and children ... whose income and resources are above the limits prescribed for the categorically needy but are within the limits set under the medicaid State plan." 20 Under a program for the medically needy, these individuals receive financial assistance, but only for health care expenses. ${ }^{21}$

To qualify as medically needy under current federal regulations, a person must be "linked" to a categorical assistance program ${ }^{22}$-in other words, bear all the characteristics of a recipient of cash assistance, except for his or her income and other financial

1742 U.S.C. $\$ 1396 a(a)(10)(A)$ (1976). Categorically needy persons are saged, blind or disabled individuals or families and children ... who meet the financial eligibility requirements for AFDC [Aid to Families with Dependent Children], SSI [Supplemental Security Income], or an optional State [cash assistance] supplement." 42 C.F.R. $\$ 435.4$ (1979).

The AFDC program is codified at 42 U.S.C. $\$ \$ 601-611$ (1976 \& Supp. II 1978). It is a cooperative federal-state program that provides cash assistance payments

to needy dependent children and the parents or relatives with whom they are living to help maintain and strengthen family life and to help such parents or relatives to attain or retain capability for the maximum selfsupport and personal independence consistent with the maintenance of continuing parental care and protection.

42 U.S.C. $\$ 601$ (1976).

SSI, a federal program that provides cash payments to the aged, blind, and disabled, is codified at 42 U.S.C. $\$ \$ 1381-1383 \mathrm{c}$ (1976 \& Supp. II 1978). It was enacted in 1972 to replace the three previously existing

[s]tate-administered programs of assistance to the aged, blind, and disabled with one combined adult assistance program which would be Federally administered by the Social Security Administration and would have nationally uniform requirements for such eligibility factors as the level and type of resources allowed and the degree of disability or blindness.

H.R. Rpp. No. 231, 92d Cong., 2 d Sess. 4, reprinted in [1972] U.S. CodE Cong. \& AD. News 4989, 4992.

1842 U.S.C. $\$ 1396 a(a)(10)(C)(i)(1976)$.

19 The Department of Health, Education, and Welfare (HEW) was redesignated the Department of Health and Human Services by the Department of Education Organization Act, Pub. L. No. 96-88, $\$ 509,93$ Stat. 668 (codified at 20 U.S.C. $\$ 3508$ (Supp. III 1979)). The change became effective May 4, 1980. 45 Fed. Reg. 29,642 (1980). This Comment will use the acronym "HHS" throughout, including references to actions by HEW before the name change.

2012 C.F.R. $\$ 435.4$ (1979).

2142 U.S.C. $\$ 1396 \mathrm{a}(\mathrm{a})(10)(\mathrm{C})(\mathrm{i})$ (1976). The assistance received under Medicaid is not direct cash reimbursement, but payment to the provider of medical services.

22 Checking the Legality of Your State's Medically Needy Income Levels, 13 Clearunghouse Rev. 755, 757 (1980). 
resources. Thus, medically needy families must have the same nonfinancial characteristics as recipients of cash payments under the Aid to Families with Dependent Children (AFDC) program, ${ }^{23}$ and medically needy individuals must be aged, blind, or disabled-the nonfinancial characteristics of recipients of cash payments under the federal Supplemental Security Income (SSI) program. ${ }^{24}$

SSI recipients are among the categorically needy who must be covered by states participating in the Medicaid program. ${ }^{25}$ Prior to a 1980 amendment to the SSI program, ${ }^{28}$ SSI applicants were expressly permitted to transfer resources that, if retained, would have made them ineligible to receive cash assistance. ${ }^{27}$ Resources could be given away or sold for less than adequate consideration ${ }^{28}$ without precluding eligibility for SSI. ${ }^{29}$ The divergence between this federal rule and several state rules denying Medicaid benefits to medically needy persons who divested themselves of assets prior to application for benefits gave rise to litigation that has split the courts ${ }^{30}$ and culminated in the 1980 legislative attempt to solve the problem. $^{\text {31 }}$

The meager cash payments distributed under the SSI program provide little incentive to divest oneself of substantial assets merely to receive SSI benefits. ${ }^{32}$ In contrast, because the potential

23 This means that there must be a qualifying dependent child in the family. 42 C.F.R. $\$ 435.310$ (1979). See note 17 supra.

2442 C.F.R. $\$ \$ 435.320-.325$ (1979). See note 17 supra.

2542 U.S.C. $\$ 1396 a(a)(10)(A)$ (1976). One option in the Medicaid statute does permit states to cover fewer than all SSI recipients, provided the state does not use requirements that are more restrictive than those in effect in January 1972. 42 U.S.C. $\$ 1396 \mathrm{a}$ (f) (1976). This is the so-called " $209(\mathrm{~b})$ " option, added by the Social Security Amendments of 1972, Pub. L. No. 92-603, $\S 209$ (b), 86 Stat. 1329. For a discussion of the 209 (b) option, see Norman v. St. Clair, 610 F.2d 1228, 1231-32 (5th Cir. 1980), petition for cert. fled sub nom. Harris v. Norman, 49 U.S.L.W. 3271 (U.S. Sept. 27, 1980) (No. 80-498). See note 43 infra.

26 Social Security Amendments of 1980, Pub. L. No. 96-611, $\$ 5(a), 94$ Stat. 3567 (to be codified in 42 U.S.C. $\$ 1382 \mathrm{~b}$ ). The new SSI rule became effective March 1, 1981, "the first day of the first month which [began] at least 60 days after the enactment of this Act." Id. $\$ 5(\mathrm{c})$.

2742 U.S.C. $\$ 1382 b(b)$ (1976); 42 C.F.R. $\$ 435.120$ (b) (1979).

28 Adequate consideration is generally interpreted as fair market value. See H.R. REP. No. 1167, 96th Cong., 2d Sess. 85 (1980).

29 Soctal Securtty Ad., Dep'T of Healtir and Httman Services, Soctal Securtix Clatms Mandat \$12507(a) (1977) [hereinafter cited as Soctax Securtrt Clamss Manuad].

30 See notes 10 \& 11 supra \& accompanying text.

31 Social Security Amendments of 1980, Pub. L. No. 96-611, $\$ 5(a)$, 94 Stat. 3567 (to be codified in 42 U.S.C. $\$ 1382 \mathrm{~b}$ ).

32 Brief on Behalf of Appellant at 24, Caldwell v. Blum, 621 F.2d 491 (2d Cir.), petition for cert. filed, 49 U.S.L.W. 3005 (U.S. June 24,1980 ) (No. 79-2034). SSI benefits to an eligible individual were payable at the rate of $\$ 146$ per month between July 1, 1974, and June 30,1975 , and at the rate of $\$ 157.70$ 
cost of long-term institutional care is huge, the temptation to transfer assets in order to receive Medicaid benefits may be very real. The Senate report accompanying an unenacted 1979 bill observed that

[w] here an individual with significant assets is faced with the prospect of substantial medical expenses-particularly in cases where a prolonged period of institutionalization may be needed-present law may provide a strong incentive for him to give those assets away to a friend or relative so as to qualify for medicaid immediately. To the extent that this happens, the costs of the program are increased since medical expenses which could be met from the individual's assets are instead being paid for by public funds. ${ }^{33}$

The new legislation is not likely to change these incentives. Although the legislation places restrictions on asset transfers by SSI applicants and gives states some flexibility in creating their own policies affecting medically needy Medicaid applicants, it does not alter the benefits received. The dilemma remains-the creation of an asset transfer rule that both accommodates the states' concerns and protects deserving applicants.

\section{B. Significance}

The difficulties in meeting the long-term health care needs of the elderly population are for several reasons likely to intensify in the near future. ${ }^{34}$ First, the elderly population is increasing. One commentator has noted that

[i]n 1977, 23.5 million people-one in every nine persons in the United States-were sixty-five years of age or older. By 2010, when the "baby boom" children are only beginning to reach age sixty-five, the number of elderly persons in this country is expected to be thirty-

thereafter. 20 C.F.R. $\$ 416.410$ (1980). Cost-of-living adjustments may be made, id. $\$ 416.405$, but the amount of cash an individual actually receives is reduced by his nonexcludable income, $i d$. \$416.410. Examples of excludable income are benefits provided under another federal program, state cash assistance based on need, disaster relief assistance, and limited amounts of earned income. 45 Fed. Reg. 65,549-50 (1980) (to be codified in 20 C.F.R. $\$ \$ 416.1112-.1124$ ).

33 S. Rez. No. 471, 96th Cong., Ist Sess. $48-49$ (1979). See also Brief for Appellees at 16, Dawson v. Myers, 622 F.2d 1304 (9th Cir.), cert. granted sub nom. Beltran v. Myers, 101 S. Ct. 353 (1980).

84 See generally Comment, Continuing-Care Communities for the Elderly: Potential Pitfalls and Proposed Regulation, 128 U. PA. L. REv. 883 (1980). 
four million. That number is expected to reach fifty-two million by 2030 , at which time the proportion of our populace over sixty-five should peak at somewhere between fourteen and twenty-two percent. ${ }^{35}$

Second, the cost of health care is increasing dramatically, approaching ten percent of the gross national product. ${ }^{36}$ Third, for at least some elderly individuals with chronic ill health, entry into a longterm care facility represents more than an arrangement for medical or nursing care-it represents an indefinite and perhaps permanent living situation. ${ }^{37}$

An elderly person's desire to give his house or other assets accumulated during his lifetime to his children is understandable. Using his assets to pay for health care may defeat his lifelong plans. The states' concerns, however, must also be recognized. Hospital and long-term care services currently represent two-thirds of Medicaid benefits costs. ${ }^{38}$ The aged, blind, and disabled, who are most likely to need these services, account for approximately sixty-four percent of Medicaid expenditures. ${ }^{39}$ It is neither unreasonable nor unjust to expect that an individual's assets will help defray

35 Id. 883 (footnotes omitted).

36 U.S. News AND WorLd Report, Sept. 1, 1980, at 44.

In addition to the increasing cost of medical care generally, studies have revealed a shortage of facilities for the elderly who need institutional care. For example, the vast majority of long-term care beds in the New York City area in 1977 was occupied by individuals seventy-five years of age or older. Healma Systems Agency of New Yort City, Acute Care Hospttal Report G-61 (1980). The size of the population over age 75 in New York City is expected to increase from 382,726 in 1977 to 403,984 by 1984. Id. G-75. Patients in acute care hospitals who need to be transferred to long-term care facilities already outnumber the available beds. Id. G-26. The shortage will continue; between 1,315 and 2,115 additional beds will be required to meet the shortfall projected for longterm care requirements in 1981. 1d. G-33. Similarly, in southeastern Pennsylvania, the number of elderly persons eligible for Medicaid who could not be placed in long-term care facilities in 1979 greatly exceeded the number of nonelderly persons eligible for Medicaid who also could not be placed. Healta Systems Agency of Southeastern Pennsylvanda, Supplement to the Proposed Healti Systems Plan: Data and Reference Materials A-LT 1-9, A-LT 7-2 (1980).

Other serious problems that beset the elderly include overutilization of institutional care due to the lack of noninstitutional alternatives, see Butler, Financing Noninstitutional Long-Term Care Services for the Elderly and Chronically Ill: Alternatives to Nursing Homes, 13 Crearingaouse Rev. 335, 336 (1979) (estimating that between $10 \%$ and $40 \%$ of institutionalized elderly persons are inappropriately placed), and woefully inadequate, frequently abusive, institutional care, see $M$. Mendeison, Tender Loving Greed (1974).

${ }^{37}$ See Health Systems Agency of New York Ciry, Acute Care Hospitax Report G-46 (1980); Brief for Appellants at 8, Dawson v. Myers.

38 [1979-1 Transfer Binder] Medicare and Medicam Guwe (CCH) I $29,592$. 38 Id. 
the cost of what may become a permanent living arrangement. Nevertheless, several of the cases invalidating state asset transfer rules indicate that the existence of a sympathetic applicant may unduly influence the results. ${ }^{40}$

It is important to look beyond appealing facts to the larger issues presented by the cases and to acknowledge that the states' legitimate concern for preventing fraud and abuse must be accommodated. States are under no obligation to provide Medicaid coverage for the medically needy; ${ }^{41}$ at present, eighteen states have no coverage, while others have elected to use eligibility requirements for all Medicaid recipients that are more restrictive than SSI requirements. ${ }^{42}$ Although Congress's decision to permit the states to impose asset transfer rules is preferable to the likely alternative-restriction or complete termination of Medicaid coverage by the states ${ }^{43}$-the states' rules must be structured and applied to guard

40 See notes 102-07 infra \& accompanying text.

4142 U.S.C. $\$ 1396 \mathrm{a}(\mathrm{a})(10)(\mathrm{C})(\mathrm{i})$ (1976).

42 States excluding the medically needy from coverage under their Medicaid programs include: Alabama, [1980] 3 Medicare aND MEDICAm GUDE (CCH) II 15,550; Alaska, id. I 15,552; Colorado, id. I 15,564; Delaware, id. I 15,568; Florida, id. II 15,572; Georgia, id. II 15,574; Iowa, id. I 15,586; New Jersey, id. I 15,616; New Mexico, id. \15,618; Ohio, id. I 15,626; South Carolina, id. I 15,638; South Dakota, id. I 15,640; Texas, id. I 15,644; Wyoming, id. If 15,660; Idaho, [1979] 3 MEDICARE AND MEDICAm GuIDE (CCH) If 15,580; Indiana, id. II 15,584; Missouri, id. \15,606; and Nevada, id. I 15,612. For a list of states using eligibility requirements that are more restrictive than those for SSI, see note 43 infra.

43 See Medically Needy Levels for Aged, Blind and Disabled Are Often Illogically Low and Should Be Challenged, 13 Crearnnghouse Rev. 599 (1979).

New York, in response to the court decisions invalidating its transfer of assets rule, Caldwell v. Blum, 621 F.2d 491 (2d Cir. 1980), petition for cert. filed, 49 U.S.L.W. 3005 (U.S. June 24, 1980) (No. 79-2034), and Scarpuzza v. Blum, 73 A.D.2d 237, 426 N.Y.S.2d 505 (1980), has exercised its option under the federal Medicaid statute, 42 U.S.C. \$1396a(f) (1976) (the "209(b) option"), to evaluate Medicaid applicants by using resource eligibility requirements that are more restrictive than those under SSI. One New York legal services organization estimates that as many as $20 \%$ of SSI recipients have lost Medicaid eligibility in other states when the 209(b) option has been exercised. 6 GULP Newsletter 3 (Sept. 1980) (published by Greater Upstate Law Project, Rochester, New York). See note 25 supra.

Besides New York, 209(b) states include: Connecticut, [1980] 3 Medrcare AND MEDICAID GumE (CCH) I 15,566; Hawaii, id. I 15,578; Illinois, id. I 15,582; Indiana, id. I 15,584; Minnesota, id. II 15,602; Mississippi, id. II 15,604; Nebraska, id. I 15,610; New Hampshire, id. I 15,612; North Carolina, id. II 15,622; North Dakota, id. I 15,624; Ohio, id. \ 15,626; Utah, id. \ 15,646; Virginia, id. II 15,652; and Missouri, [1979] 3 MEDICARE AND MEDICAID GumE (CCH) $\uparrow$ 15,606.

Of the states providing medically needy coverage and ostensibly using SSI eligibility criteria, several had asset transfer rules even before federal law authorized such rules. These states include: California, CAL. WELF. \& INST. CoDE $\$ 14015$ (West 1980); Massachusetts, Mass. ANN. Laws ch. 118E, §13 (Michie/ Law. Co-op 1975); Michigan, Interview with Robert Rosenberg, Michigan Attomey General's Office (Jan. 8, 1981) (applied as an administrative policy); Pennsylvania, Pa. Stat: ANN. tit. 62, $\$ 441.2$ (Purdon Supp. 1980); Tennessee, Tenn. Code 
against the unjust denial of essential Medicaid benefits to individuals who cannot control the distribution of their "assets." 4

\section{Asset Transfer Rules and the Courts}

\section{A. Conflicting Statutory Interpretations}

Actions brought by medically needy Medicaid applicants challenging state transfer of assets rules have divided the courts of appeals. Dawson $v$. Myers, ${ }^{45}$ for example, was a class action attack on California's asset transfer rule. ${ }^{46}$ Under that rule an applicant for Medi-Cal ${ }^{47}$ transferring assets for inadequate consideration within two years before application is ineligible for benefits, unless he can rebut the presumption that he made the transfer to establish eligibility or to reduce his share of medical costs. ${ }^{48}$

The district court hearing the case granted the State of California's motion for summary judgment. ${ }^{49}$ The Ninth Gircuit affirmed, holding that the California statute and implementing regulations do not conflict with federal statutes or regulations, ${ }^{50}$ do not

ANN. $\$ 14-23-118$ (1980); and Wisconsin, WIs. STAT. ANN. $\$ 49.47$ (4)(d) (West Supp. 1980).

A federal district court has ruled that the Massachusetts statute conflicts with federal law. Robinson v. Pratt, No. 79-1278-S (D. Mass. June 24, 1980). At first, however, the court refused to enjoin enforcement of the statute, stating that the proper remedy would be for the secretary of HHS to withhold federal payments from the Massachusetts Medicaid program. Id. The same judge has since issued a preliminary injunction requiring HHS to withhold funds and commence proceedings against the state. Robinson v. Pratt, No. 79-1278-S (D. Mass. Sept. $18,1980)$.

An interesting contrast to the Massachusetts transfer of assets rule is a provision recently enacted by the Massachusetts legislature establishing a scheme to aid the mentally retarded in transferring funds into trusts so that they may become eligible for Medicaid or SSI. 1980 Mass. Adv. Legis. Serv. ch. 329, $\$ 45$.

44 See notes 172-76 infra \& accompanying text.

45622 F.2d 1304 (9th Cir.), cert. granted sub nom. Beltran v. Myers, 101 S. Ct. 353 (1980). This case created the circuit split on the question whether asset transfer rules conflicted with federal law.

46 Car. Wex. \& INST. Code $\$ 14015$ (West 1980).

47 California's Medicaid program is called "Medi-Cal." The terms "Medicaid" and "Medi-Cal" will be used interchangeably to refer to the California program. 4822 Car. An. Code $\$ 50409$, quoted in Brief for Appellees at 7-8, Dawson v. Myers, 622 F.2d 1304 (9th Cir.), cert. granted sub nom. Beltran v. Myers, 101 $\mathrm{S}$. Ct. 353 (1980). The regulation establishes that only objective facts may be used to rebut the presumption. Statements of subjective intent, such as intent to avoid probate or lack of knowledge concerning the availability of Medi-Cal benefits, are not relevant. Objective facts include "evidence that adequate resources were available at the time of the transfer of property for support and medical care considering such things as the applicant's or beneficiary's age, health, life expectancy, and ability to understand extent of resources." Id. $\$ 50409$ (b) (2).

49 Dawson v. Beach, No. CV-78-2350-MML (C.D. Cal. May 10, 1979).

50622 F.2d at 1312-14. See notes 62-64 infra for the text of the applicable federal statutes and regulations. 
deny the applicants due process of law, ${ }^{51}$ and do not violate the equal protection clause of the Constitution. ${ }^{52}$

Similarly, Caldwell v. Blum ${ }^{53}$ involved a class action challenge to New York's asset transfer rule by elderly medically needy individuals residing in that state. The New York law presumed that a transfer of any property within eighteen months prior to application for Medicaid benefits was made for the purpose of qualifying for benefits. ${ }^{54}$ Certain items of property, such as a homestead and essential personal property, were not counted in determining an applicant's eligibility for benefits. ${ }^{55}$ If an applicant transferred even that exempt property for inadequate consideration within eighteen months before application or at any time after application, however, he was presumed to have done so "for the purpose of defeating any current or future right to recovery of medical assistance paid, or for the purpose of qualifying for, continuing eligibility for or increasing need for medical assistance." 56 The applicant had the burden of proving to a social services official that the transfer was not made for the proscribed purpose. ${ }^{57}$

The district court granted a preliminary injunction against enforcement of the New York statute and implementing regulations. ${ }^{68}$ The Second Circuit Court of Appeals affirmed on the ground that the New York law conflicted with the federal statue and HHS regulations. ${ }^{59}$

The conflict between the two circuits revolves primarily around two provisions of subchapter XIX of the Social Security

51 622 F.2d at 1314 .

52 Id. 1315.

53621 F.2d 491 (2d Cir.), petition for cert. filed, 49 U.S.L.W. 3005 (U.S. June 24, 1980) (No. 79-2034).

54 N.Y. Soc. SERv. Law $\$ 366$ (1) (e) (McKinney Supp. 1980).

65 Id. $\$ 366(2)$ (a) (McKinney 1976 \& Supp. I980).

58 Id. $\$ 366$ (I) (e) (McKinney Supp. 1980).

5718 N.Y. Code R. \& REg. $\$ 360.8$ (1978). The New York regulations require only proof "to the satisfaction of the social services official," $i d$. Cf. note 48 supra (use of objective facts required in California).

58 Caldwell v. Blum, No. 78-CV-569 (N.D.N.Y. Dec. 3, 1979).

50621 F.2d at 497-98. See notes $62-64$ infra for the text of the applicable federal statutes and regulations.

The United States Supreme Court has twice refused to stay the Second Circuit's order in Caldwell. In a short opinion announced prior to the Ninth Circuit's decision in Dawson, Justice Marshall refused New York's request to stay the injunction, declaring that the state had failed to meet its twin burdens of proving both irreparable harm and the likelihood that four members of the Supreme Court would vote to grant certiorari. Blum v. Caldwell, 100 S. Ct. 1635 (Marshall, Circuit Justice, 1980). A second request was denied by the full Court, without opinion. Blum v. Caldwell, 100 S. Ct. 2959 (1980). A petition for certiorari has nevertheless been filed. Caldwell v. Blum, 49 U.S.L.W. 3005 (U.S. June 24, 1980) (No. 79-2034). 
Act ${ }^{60}$ and an HHS implementing regulation. ${ }^{61}$ The first statutory section, or comparability provision, requires that a state electing to cover the medically needy furnish medical assistance to all individuals who, but for their incomes and other resources, would be considered categorically needy, yet who have insufficient funds to meet their medical costs. The insufficiency of incomes and resources is to be evaluated "in accordance with comparable standards." 62 The second troublesome section, or availability provision, requires that a state Medicaid plan take into account only the income and resources that are "available to the applicant." ${ }^{63}$ The disputed HHS regulation (subsection 401 (c)) requires that state plans not use eligibility requirements for the medically needy aged, blind, and disabled that are more restrictive than those used under the SSI program. ${ }^{.4}$

The Caldwell court relied on the comparability provision ${ }^{65}$ to reach its holding that New York's imposition of "more restrictive eligibility requirements on the medically needy than on the cate-

60 Subchapter XIX is the Medicaid statute, codified at 42 U.S.C. $\$ \S 1396-$ 1396k (1976 \& Supp. II 1978).

6142 C.F.R. $\$ 435.401$ (c) (1979).

62 Under the statute, a state plan for the medically needy must provide

for making medical assistance available to all individuals who would, except for income and resources, be eligible for aid or assistance under any such State plan or to have paid with respect to them supplemental security income benefits under subchapter XVI of this chapter, and who have insufficient (as determined in accordance with comparable standards) income and resources to meet the costs of necessary medical and remedial care and services.

42 U.S.C. $\$ 1396 \mathrm{a}(\mathrm{a})(10)(\mathrm{C})(\mathrm{i})(1976)$ (emphasis added).

63 The statute requires the state to

include reasonable standards ... . for determining eligibility for and the extent of medical assistance under the plan which . . . provide for taking into account only such income and resources as are, as determined in accordance with standards prescribed by the Secretary, available to the applicant or recipient and ... as would not be disregarded (or set aside for future needs) in determining his eligibility for [a cash assistance program].

42 U.S.C. $\$ 1396 a(a)(17)$ (1976) (emphasis added).

64 The regulation reads:

The agency must not use requirements for determining eligibility for optional coverage groups that are-

(1) For families and children, more restrictive than those used under the State's AFDC plan; and

(2) For aged, blind, and disabled individuals, more restrictive than those used under SSI, except for individuals receiving an optional State supplement as specified in $\$ 435.230$ or individuals in categories specified by the agency under $\$ 435.121$.

42 C.F.R. $\$ 435.401$ (c) (1979) (emphasis added).

65 Caldwell v. Blum, $621 \mathrm{~F} .2 \mathrm{~d}$ at $495-96$. 
gorically needy" 60 justified a preliminary injunction against enforcement of the state's rule. ${ }^{67}$ It rejected the state's argument, based on congressional committee reports accompanying the original Medicaid legislation, ${ }^{68}$ that the comparability provision was intended to assure comparable treatment among only the various medically needy groups-the aged, blind, disabled, and families and children-rather than between the medically needy and the categorically needy. Conceding that "the State's argument is not without some force," 69 the court nevertheless dismissed it and declared that because "the aged, blind and disabled medically needy must be treated comparably as between each other does not mean that as a group (the medically needy) they should not be treated comparably with the categorically needy." 70 It found support for this conclusion in the HHS subsection 401(c) regulation and noted that HHS "has promulgated a number of regulations on comparability ... which have been invariably upheld by the court." 71 The court also quoted the availability provision, noting that it "buttressed" 72 the applicants' argument and concluding that " for persons such as plaintiffs . . . state standards must provide that income which is disregarded in determining SSI eligibility also be disregarded in determining eligibility for and the extent of medical assistance under Medicaid." "73
Be Id. 494.
67 Id. 498-99.
68 The legislative history quoted in the opinion reads:
The committee bill would make more specific a provision now in the law that in determining eligibility for and the extent of aid under the plan, States must use reasonable standards consistent with the objectives of the titles. Although States may set a limitation on income and resources which individuals may hold and be eligible for aid, they must do so by maintaining a comparability among the various categorical groups of needy people. Whatever level of financial eligibility the State determines to be that which is applicable for the eligibility of the needy aged, for example, shall be comparable to that which the State sets to determine the eligibility for the needy blind and disabled; and must also have a comparability to the standards used to determine the eligibility of those who are to receive medical assistance as needy children and the parents or other relatives caring for them.

S. Rep. No. 404, 89th Cong., Ist Sess. 77-78, reprinted in [1965] U.S. Code Cong. \& AD. News 1943, 2018.

60621 F.2d at 497.

$70 \mathrm{Id}$.

71 Id. 497 \& n.8 (footnote omitted).

72 Id. 496.

73 Id. (quoting Friedman v. Berger, 547 F.2d 724, 728 (2d Cir. 1976), cert. denied, 430 U.S. 984 (1977)). In Friedman, the Second Circuit rejected a suit by institutionalized medically needy plaintiffs seeking to invalidate a New York regulation that restricted the amount of income they could retain to $\$ 28.50$ per month. The court found that there was comparable treatment between the medically and categorically needy. 
The Ninth Circuit, construing the same statute and regulation in Dawson, reached the opposite conclusion. It disposed of the comparability provision by dividing it into two parts:

The first part specifically excepts income and resources when it equates SSI eligibility to the medically needy eligibility requirements. And so, while this provision does extend all of the SSI eligibility requirements to the medically needy, it does not do so for those which deal with the applicant's income and resources. Were this not the case, then there would be no distinction between the two groups. ${ }^{74}$

The second part of the comparability provision, according to the court, "only requires the standards to be comparable, not identical. ... The [standards other than the asset transfer rule] which are used for determining financial eligibility are similar enough to invite comparison." 75

In rejecting the applicants' argument that the California statute conflicts with the availability provision of the federal statute, the court refused to define "availability" literally by equating it with "present record title or ownership." 78 The court found support for this interpretation in an HHS regulation allowing states to consider income for a six-month prospective period when determining eligibility. ${ }^{77}$ Because the regulation permits evaluation of future income, the court concluded that a state "should also be allowed to consider those assets which have been recently disposed of under circumstances which indicate that the purpose was to qualify for public medical assistance." 78

The unique element of the Dawson court's approach was its close look at the relevant HHS regulations. Other courts ${ }^{79}$ have relied primarily on the subsection 401 (c) regulation requiring a

74 Dawson v. Myers, 622 F.2d at 1310-11 (emphasis in original).

75 Id. 1311.

70 Id. 1312.

77 Id. 1313. The regulation cited by the court states: "The agency must determine income eligibility of medically needy individuals in accordance with this section. The agency must use a prospective period of not more than 6 months to compute income." 45 Fed. Reg. 24,886 (1980) (to be codified in 42 C.F.R. $\$ 435.831$ ).

78622 F.2d at 1313. It does not follow logically that permission to consider assets retroactively is necessarily implicit in a regulation permitting consideration of future income. On the contrary, there is a difference between resources that have been disposed of and income that is still coming in.

79 E.g., Caldwell, 621 F.2d at 495; Fabula v. Buck, 598 F.2d 869, 872-73 (4th Cir. 1979); Scarpuzza v. Blum, 73 A.D.2d 237, 247, 426 N.Y.S.2d 505, 512 (1980). 
state to use no more restrictive eligibility requirements for the medically needy than for the categorically needy. ${ }^{80}$ In its discussion, the Dawson court first noted that to read the regulation the way the applicants did "would be [to read] an inconsistency into the federal statutory and regulatory framework. The Medicaid program is designed to provide benefits to two differently situated groups. . . . By definition, different financial requirements apply to the medically needy than to the categorically needy." 81 The second and more persuasive point made by the court was that the subsection 401(c) regulation, upon which the applicants and other courts relied so heavily, is one of a group of HHS regulations establishing general eligibility requirements: ${ }^{82}$ "There is absolutely no discussion of financial eligibility requirements in any of the other sections of this subpart. Instead, the focus of all of the sections is directed toward much more general concerns, such as eligibility requirements which are based on citizenship, alienage, or state residence." 83 Without discussing them, the court noted that three other subparts of the regulations describe the financial eligibility requirements. It declared that these specific regulations, which establish rules for evaluating the resources of a medically needy applicant, ${ }^{84}$ supersede the more general eligibility rules. ${ }^{85}$

The Dawson and Caldwell courts both discussed a series of letters, written by HHS regional directors to state officials in New York and Michigan and to a legal services program in California, stating that asset transfer rules are invalid as applied to the medically needy. ${ }^{88}$ The Caldwell court accorded some weight to these letters ${ }^{87}$ and deferred to the HHS interpretation of the statute. ${ }^{88}$ But the Dawson court, while recognizing the principle that a "court generally defers to an administrative agency's interpretation of the

80 For text of the regulation, see note 64 supra.

$81622 \mathrm{~F} .2 \mathrm{~d}$ at 1313 (emphasis in original).

82 Id. See 42 C.F.R. $\$ \$ 435.400-404$ (1979).

83622 F.2d at 1313.

84 See text accompanying notes 132-38 infra; 42 C.F.R. $\$ 435.845$ (1979); 45 Fed. Reg. 24,886 ( 1980 ) (to be codified in 42 C.F.R. $\$ 435.845(\mathrm{e})$ ).

85622 F.2d at 1313-14. See 42 C.F.R. $\$ \$ 435.800-.845$ (1979); 45 Fed. Reg. 24,886 (1980) (to be codified in 42 C.F.R. $\$ 435.845$ (e)).

86 The Fabula court also discussed these letters. 598 F.2d at $873 \&$ n.10.

87621 F.2d at 495 . In addition to noting the letters, the district court opinion in Caldwell pointed out that "in the [HHS] Compliance Report for the quarter ending June 30, 1978, New York State was officially cited as being out of compliance with federal requirements on the same basis." Caldwell v. Blum, No. 78-CV-569, slip op. at 11 (N.D.N.Y. Dec. 3, 1979).

88621 F.2d at 497. The Fabula court also deferred to HHS. $598 \mathrm{~F} .2 \mathrm{~d}$ at 873. 
law which it is charged with administering," 89 refused to defer to the HHS interpretation in this case. The court immediately followed this refusal with a summary rejection of the HHS letters, stating that HHS "as a whole has approved California's Medi-Cal program (and the transfer rule).... [N]ot only do we believe that the letter rulings should not be followed, but we also believe that [HHS's] general acceptance of California's Medi-Cal program supports our interpretation." 90

The Dawson court's reliance on HHS's general approval of an entire program in the face of the agency's very specific letters to the contrary is at best contrived. A better view is that such general approval of a state plan "is not more than slightly persuasive when, as here, the so-called approval does not appear to have followed explicit attention to the question now confronted." 91 The Dawson court wished to reject the HHS interpretation of the statute and did so. In view of the HHS letters, the Ninth Circuit's effort to find support for that rejection in HHS's casual approval of the entire California program is questionable. ${ }^{92}$

89622 F.2d at 1311. See New York Dep't of Social Servs. v. Dublino, 413 U.S. 405, 421 (1973) (quoting Red Lion Broadcasting Co. v. FCC, 395 U.S. 367, 381 (1969)).

90 622 F.2d at 1311. The court made this statement despite extensive argument in appellants' brief, which included the text of one of the letters and a discussion of the Fabula court's treatment of the issue. Brief for Appellants at 15-17, Dawson v. Myers.

91 Fabula, 598 F.2d at 873 n.11 (quoting Aitchison v. Berger, 404 F. Supp. 1137, 1148 (S.D.N.Y. 1975), affd mem., 538 F.2d 307 (2d Cir.), cert. denied, 429 U.S. 890 (1976)). See also Rosado v. Wyman, 397 U.S. 397, 406-07 (1970).

92 AFDC eligibility cases and the literature concerning them have established that "state determinations as to need and level of benefits are given far greater latitude than regulations concerning eligibility." Block, Cooperative Federalism and the Role of Litigation in the Development of Federal AFDC Eligibility Policy, 1979 Wrs. L. REv. 1, 2 (1979) (emphasis added).

The leading cases invalidating state rules that restricted AFDC eligibility are King v. Smith, 392 U.S. 309 (1968) (Alabama regulation denying AFDC payments to children of a woman who cohabited with an able-bodied man invalidated under supremacy clause because Congress intended "parent" to mean only those with a legal duty to support a child), Townsend v. Swank, 404 U.S. 282 (1971) (Inlinois statute denying AFDC payments to eighteen to twenty year-old college students invalidated because the Social Security Act's definition of a dependent child included college students in that age group), and Carleson v. Remillard, 406 U.S. 598,602 (1972) (California regulation denying AFDC payments to needy families when a parent was absent for military service invalidated because the federal eligibility criterion requiring a parent to be absent from the home "accurately describe[d] a parent on active military duty").

Using these AFDC eligibility cases, the applicants in Dawson argued that "states are not permitted to deprive otherwise eligible individuals of benefits by the use of restrictive eligibility criteria which are not included in the federal legislation." Brief for Appellants at 22, Dawson v. Myers. In a conclusory footnote the court rejected this argument, stating that it was "unable to find any provision of the statute which said this." 622 F.2d at 1310 n.8. 
Equally unsatisfactory is the Caldwell court's discussion of the legislative history. In rejecting New York's argument that the sole purpose of the comparability provision was to assure comparable treatment among the various groups of medically needy people, ${ }^{93}$ the court thought more highly of subsequent legislative interpretations than of contemporaneous legislative history.94 Attempts to amend the Social Security Act to explicitly authorize state imposition of asset transfer rules, ${ }^{95}$ with the attendant implication that the

The Dawson court did not discuss any of the aforementioned AFDC cases. Instead, it relied on a later case, New York Dep't of Social Servs. v. Dublino, 413 U.S. 405,413 (1973), to support its conclusion that, because of the cooperative federal-state nature of the Medicaid program, it would be inappropriate to invalidate an eligibility requirement that Congress had failed to prohibit in the Medicaid statute. 622 F.2d at 1310 n.8.

The Fabula court, on the other hand, cited Townsend to support its conclusion that Maryland could not use an eligibility requirement that was more restrictive than the federal requirements. Fabula, 598 F.2d at 873.

See Comment, HEW's Power to Grant AFDC Benefits to Technically Ineligible Individuals, 124 U. PA. L. Rev. 1359 (1976), for an exhaustive discussion of the Ring, Townsend, and Remillard cases. The Comment notes the "wellsettled principle that [HHS] may not accept a state plan that excludes from coverage persons who are eligible for AFDC under federal standards unless the exclusion is permitted by the Act itself." Id. 1359-60. It argues that the Court's "leniency" to state rules in Dublino "must be viewed in light of its remanding the case to determine whether the state work rules did in fact "contravene the purposes or provisions of [the federal statute]." Id. 1372-73 n.96 (quoting Dublino, 413 U.S. at 423).

More recently, however, it has been suggested that the King, Townsend, and Remillard cases have been read in an "overly broad manner." Block, Cooperative Federalism and the Role of Litigation in the Development of Federal AFDC Eligibility Policy, 1979 Wis. L. Rev. 1, 17 (1979). See also Burns v. Alcala, 420 U.S. 575, 580 (1975).

The result, although not the reasoning, of Townsend has been overruled by a recent statute. Social Security Amendments of 1980, Pub. I. No. 96-611, $\$ 4$, 94 Stat. 3567 (to be codified in 42 U.S.C. $\$ 606(a)(2)$ ) (giving states the option to provide AFDC benefits only to students aged eighteen to twenty-one who are in high school or are participating in vocational training).

93 See note 68 supra and text accompanying notes 68-70 supra.

94621 F.2d at 497-98. See text accompanying notes 97 \& 98 infra.

95 A report written to accompany H.R. 934, 96th Cong., 1st Sess. (1979), states in part:

The bill permits States to deny medical assistance to any aged, blind, or disabled person (including individuals who are not "categorically ineligible") who has given away assets in order to meet the medicaid eligibility requirements (or has "sold" such assets for less than their fair market value).

The bill would allow States the option of denying or limiting eligibility in this type of situation. If a State chooses to make use of this provision, an aged, blind, or disabled person would be considered (for purposes of medicaid eligibility) to still possess a disposed-of asset for a period of 12 months if he gave it away in order to become eligible for medicaid.

S. Rep. No. 471, 96th Cong., Ist Sess. $48-49$ (1979). See also S. Rep. No. 1111, 95th Cong., $2 d$ Sess. 24-25 (1978). 
Act had not previously authorized such restrictions, tended to confirm to the court the HHS interpretation of the statute. ${ }^{96}$

Using legislative history in this manner is dubious. Indeed, the same court in an earlier case declared that "pronouncements by a subsequent Congress are not entitled to the same weight as those of the Congress which enacted a measure." 97 The Supreme Court has expressed similar sentiments regarding subsequent legislative history. ${ }^{98}$

\section{B. Fraud Prevention Versus Legitimate Need}

Neither the Dawson decision, which would permit all restrictions on asset transfers, nor the Caldwell decision, which would prohibit all asset transfer rules, is satisfactory from a policy standpoint. Both fail to resolve the basic conflict highlighted by the cases themselves. The states have legitimate arguments for restricting the transfer of any resources by Medicaid applicants, even those resources excluded in eligibility determinations. ${ }^{99}$ The state rules not only express concern that eligibility for benefits may be fraudulently obtained, but also reflect the states' desire to recover the cost of Medicaid benefits out of the recipient's estate after he or she dies. ${ }^{100}$ These goals are not unreasonable. They should be met, however, so that those who truly need medical assistance are not denied benefits when there is clearly neither fraud nor an intent to cheat the state out of its recovery.

In some of the cases in which state transfer of assets rules have been challenged, variations in statutory and regulatory construction and in the degree of deference to state concerns intimate that considerations of equity may be guiding the courts. The cases recognize, some explicitly, ${ }^{101}$ that efforts to prevent fraud and abuse underlie the state statutes. The courts have attempted to harmonize that statutory intent with the needs of deserving applicants against whom asset transfer rules have been applied unfairly.

96621 F.2d at $497-98$.

97 Banco Nacional de Cuba v. Farr, 383 F.2d 166, 175 (2d Cir. 1967), cert. denied, 390 U.S. 956 (1968).

98 See, e.g., United States v. Price, 361 U.S. 304, 313 (1960). But see Red Lion Broadcasting Co. v. FCC, 395 U.S. 367, 380-81 (1969).

99 See text accompanying note 55 supra.

100 See, e.g., N.Y. Soc. SERv. Law \$366(1) (e) (McKinney Supp. 1980).

101 See, e.g., Buckner v. Maher, 424 F. Supp. 366, 373 (D. Conn. 1976), aff'd, 434 U.S. 898 (1977); Lerner v. Department of Health and Social Servs., 70. Wis. $2 \mathrm{~d} 670,680,235$ N.W.2d 478, 483 (1975). 
For example, in Buckner v. Maher, ${ }^{102}$ a class action in which a federal district court invalidated Connecticut's transfer of assets rule, the court repeatedly emphasized that the state made no allegations of fraud against any of the applicants. ${ }^{103}$ The state argued only that a transfer of resources within seven years of application for benefits, in violation of the state statute, justified denial of those benefits. ${ }^{104}$ One of the applicants, an eighty-six year-old man, had sold his home for $\$ 34,000$. During the next three years, that sum was "frittered away in numerous small transactions, under circumstances which suggest that he was the victim of individuals who took advantage of his gullibility and reduced mental capacity to divest him of his holdings." 105 If the court had upheld the Connecticut statute and regulations, he would have remained ineligible for Medicaid benefits for more than eight years. ${ }^{106}$ A second applicant, an eighty year-old man, transferred his interest in his house to his daughter in exchange for $\$ 5,000$ ten years after she had begun living with him, caring for him and the house, and paying taxes on the house. He was denied Medicaid benefits because of the state's determination-without accounting for the daughter's non-pecuniary contribution-that the true value of his interest in the house was $\$ 11,843$. He also would have remained ineligible for benefits for several years. ${ }^{107}$

102424 F. Supp. 366 (D. Conn. 1976), affd, 434 U.S. 898 (1977). The court found that the Connecticut rule conflicted with the availability provision of the federal statute, rather than with the comparability provision. Id. 373-74. See notes 63-65 supra \& accompanying text for a discussion of the two provisions. Because Buckner was summarily affirmed by the Supreme Court, it has precedential value. Hicks v. Miranda, 422 U.S. 332 (1975). See C. WrugET, HandBook of THE LAW OF FEDERAL Courts $\$ 108$ (3d ed. 1976).

In Caldwell, 621 F.2d 491, the court did not even cite the Buckner decision. In Dawson, the court cited Buckner only to "recognize that the majority of the courts which have been faced with similar challenges have reached the opposite conclusion." 622 F.2d at 1315.

103424 F. Supp. at 371, 373.

104 Id. 371-72.

$105 \mathrm{Id} .37 \mathrm{I}$.

$106 \mathrm{Id}$.

107 Id. 370. Under the Connecticut scheme, benefits were denied for whatever period of time the value of the transferred asset would have paid the individual's expenses.

Although the court insisted that the basis for its decision was conflict with federal law and not the unreasonable nature of the Connecticut rule, the opinion suggests that the cruelty with which the rule operated against the applicants in this case strongly influenced the case's outcome:

This court finds that the Connecticut rule has the effect, if not the avowed intent, of presuming that transferred assets are still available to the transferor. In many cases, such as that of an elderly Medicaid applicant 
In contrast, other cases have demonstrated the unfairness to states of invalidating all asset transfer rules. For example, in Lerner v. Department of Health and Social Services, ${ }^{108}$ a state court upheld a Wisconsin transfer of assets rule against a challenge by a single applicant. While the applicant was a private patient in a convalescent center, she transferred to her children commercial property with an estimated value of between $\$ 40,000$ and $\$ 89,000 .{ }^{109}$ Two subsequent applications for benefits were denied. The court affirmed the denial, stating that

[a]ny interpretation which finds conflict between the federal statute and the state provision would seem to allow for extensive abuse of the medical assistance program, since a failure to require the showing mandated by ... [ the state statute, that the transfer of property without consideration was not made in order to receive Medicaid benefits,] could result in any and every person who meets the income eligibility requirements automatically becoming eligible for benefits by the simple expedient of giving away or signing over control of all measurable assets. ${ }^{110}$

These case-by-case efforts to resolve the asset transfer issue in the courts have not provided satisfactory solutions. Rather, they

suffering from senility who has been cajoled out of his assets or actually defrauded, the presumption can be a cruel and irrational one.

Id. 373.

In another case, Udina $v$. Walsh, a federal district court invalidated a Missouri transfer of assets rule on the ground that it conflicted with federal law. 440 F. Supp. 1151 (E.D. Mo. 1977). Several applicants were represented. One of them owned a savings certificate with a value of $\$ 9,639$. Late in 1974, she redeemed it and gave all of the money to her father. Id. 1153. In 1975, her Medicaid and cash assistance benefits were terminated because she had transferred the certificate without consideration, despite her ability to prove at an agency hearing that the money had never been hers-her father had eamed it, and it had been kept in her name because of "family difficulties." Id. 1154.

10870 Wis. $2 d$ 670, 235 N.W.2d 478 (1975).

$100 \mathrm{Id}$. at 674,235 N.W.2d at 481.

$110 \mathrm{Id}$. at 680,235 N.W.2d at 484.

Similarly, in Rinefierd $v$. Blum, a state court upheld New York's asset transfer rule against attack by an eighty-seven year-old man who sold his home while he was in a nursing home, gave the $\$ 20,000$ in proceeds to his sons, and one year later applied for Medicaid benefits. 66 A.D.2d 351, 412 N.Y.S.2d 526 (1979). In upholding the state agency's denial of benefits, the court expressed its concern about fraud: "Since immediately prior to the time of transfer assets were available, the fact of transfer coupled with an intent later to file for benefits constitutes a species of misrepresentation or fraud undertaken for the applicant's benefit at the expense of the public fisc." Id. at 355,412 N.Y.S.2d at 529 . The court also recognized New York's interest in preventing abuse of the Medicaid program and indicated its disbelief that Congress had intended any other result. Id. at 355-56, 412 N.Y.S.2d at 529-30. Enforcement of the statute at issue in Rinefierd was later enjoined in Caldwell, 621 F.2d 491. 
have left the law in a state of confusion, ${ }^{111}$ with receipt of benefits dependent on a court's willingness to enjoin enforcement of state statutes or regulations. Now that Congress has explicitly authorized states to impose asset transfer rules, ${ }^{112}$ each state must outline precisely a plan that fairly balances the state's valid interests with those of needy individuals.

\section{ReINTERPRETING the Statute AND Regulations}

Although state asset transfer rules are now authorized explicitly by federal legislation, ${ }^{113}$ at least two reasons remain to seek a correct interpretation of the statute and regulations at issue in the asset transfer cases. ${ }^{114}$ First, the new legislation became effective on March 1, 1981,115 and cases brought before that date are still pending. ${ }^{118}$ These cases will have to be decided by the courts based on the law as interpreted before the new legislation became effective. Second, the recent legislation retains the link between SSI and Medicaid eligibility, ${ }^{117}$ but it does not resolve the issue of "comparability" between SSI and Medicaid beneficiaries. Litigation concerning this issue is likely to continue, therefore, until either Congress or the Supreme Court makes clear whether "comparable" as used in the statute should be interpreted to mean "identical" or merely "similar."

Whenever the language of a statute is ambiguous, it is appropriate to look to the congressional purposes in enacting the legis-

111 Characteristics other than appealing fact patterns also distinguish these cases. The cases upholding asset transfer rules usually have not been class actions; generally they have been tried in state courts. See, e.g., Abramson v. Welfare Comm'r, 31 Conn. Supp. 544, 330 A.2d 822 (1974); Rinefierd, 66 A.D.2d 351, 412 N.Y.S.2d 526; Lerner, 70 Wis. 2d 670, 235 N.W.2d 478. But see Scarpuzza v. Blum, 73 A.D.2d 237, 426 N.Y.S.2d 505 (1980).

The cases invalidating the rules have generally been tried in federal courts; often they have been class actions initiated by legal services attorneys. See, e.g., Caldwell, 621 F.2d 491; Fabula v. Buck, 598 F.2d 869 (1979). But see Dawson, 622 F.2d 1304.

Nonetheless, because of both the fact patterns and the courts' own recognition of the fraud/no fraud distinction, that distinction is also a valid basis on which to distinguish these cases and must be taken into account when states draft legislation to deal with the transfer of assets problem.

112 Social Security Amendments of 1980, Pub. L. No. 96-61I, $\$ 5,94$ Stat. 3567 (to be codified in 42 U.S.C. $\$ \$ 1382 b, 1396 a$ ).

$113 \mathrm{Id}$.

114 See notes 60-64 supra \& accompanying text.

116 See note 147 infra.

116 E.g., Dawson v. Myers, 622 F.2d 1304 (9th Cir.), cert. granted sub nom. Beltran v. Myers, 101 S. Ct. 353 (1980); Caldwell v. Blum, 621 F.2d 491 (2d Cir.), petition for cert. filed, 49 U.S.L.W. 3005 (U.S. June 24, 1980) (No. 79-2034). 117 See note 62 stupra for text of comparability provision. 
lation. ${ }^{118}$ The general purpose of the Medicaid program is to assist the poor in meeting the costs of health care; ${ }^{119}$ the specific purpose of the portion of the program devoted to the medically needy is to prevent the potential financial catastrophe created by high medical expenses. ${ }^{120}$ The original congressional intent in enacting Medicaid was to provide comprehensive coverage by $1975,{ }^{121}$ in terms of both persons eligible and services provided. This intent was modified, however, by the 1972 amendments to the statute, which "reflect congressional concern for state fiscal interests." 122

The language of the Medicaid statute's comparability ${ }^{123}$ and availability ${ }^{124}$ provisions, at issue in the asset transfer cases, also has been changed ${ }^{125}$ somewhat since the Medicaid program was established in 1965. There is nothing in the legislative history, however, to suggest that the intent underlying either provision has changed.126 The legislative history of the comparability provision indicates that it was intended to assure comparability between the

118 United States v. Public Utils. Comm'n, 345 U.S. 295, 315 (1953). See Chapman v. Houston Welfare Rights Org., 441 U.S. 600, 608 (1979); 2A J. Sutherrand, Statutes and Statutory Construction $\$ 45.02$ (4th ed. C. Sands 1973).

119 See, e.g., Note, Medicare and Medicaid: The Failure of the Present Health Care System for the Elderly, 17 ARz. L. Rev. 522 (1975).

120 Butler, The Medicaid Program: Current Statutory Requirements and Judicial Interpretations, 8 Clearinghouse Rev. 7, 9-10 (1974). See also S. Rep. No. 404, 89th Cong., 1st Sess., reprinted in [1965] U.S. CodE Cong. \& AD. NEws 1943.

121 The statute provided:

The Secretary shall not make payments under the preceding provisions of this section to any State unless the State makes a satisfactory showing that it is making efforts in the direction of broadening the scope of the care and services made available under the plan and in the direction of liberalizing the eligibility requirements for medical assistance, with a view toward furnishing by July 1, 1975, comprehensive care and services to substantially all individuals who meet the plan's eligibility standards with respect to income and resources, including services to enable such individuals to attain or retain independence or self-care.

Social Security Amendments of 1965, Pub. L. No. 89-97, $\$ 1903($ e), 79 Stat. 286 (repealed 1972).

122 Section 1903(e) of the original Medicaid statute, see note 121 supra, was repealed in 1972. Social Security Amendments of 1972, Pub. L. No. 92-603, $\$ 230$, 86 Stat. 1329 (codified at 42 U.S.C. \$1396b(e) (1976)). See Note, State Restrictions on Medicaid Coverage of Medically Needy Services, 78 Colum. L. REv. 1491, 1495 (1978).

12342 U.S.C. $\$ 1396 \mathrm{a}(\mathrm{a})(10)(\mathrm{C})(\mathrm{i})$ (1976). See note 62 supra.

12442 U.S.C. $\$ 1396 \mathrm{a}(\mathrm{a})(17)$ (B) (1976). See note 63 supra.

125 Act of Dec. 31, 1973, Pub. L. No. 93-233, $\$ 13(\mathrm{a})(3),(7), 87$ Stat. 947 (current version at 42 U.S.C. $\$ \$ 1396 a(a)(10),(17)(1976)$ ).

128 Sge H.R. Rep. No. 231, 92d Cong., 2d Sess., reprinted in [1972] U.S. Cons CoNG. \& AD. News 4989 (discussion of the amendments creating the SSI programs); H.R. REP. No. 627, 93d Cong., Ist Sess., reprinted in [1973] U.S. CodE Cong. \& AD. NEws 3177 (discussion of the amendments making changes in the comparability and availability provisions). 
various groups of medically needy individuals covered by the statute. ${ }^{127}$ The history of the availability provision shows that it was intended to prevent relatives (other than spouses, or parents of minor or disabled children) from being required to contribute to the medical expenses of a family member. As the Senate report accompanying the original act states:

These provisions are designed so that the States will not assume the availability of income which may not, in fact, be available or overevaluate income and resources which are available. Examples of income assumed include support orders from absent fathers, which have not been paid or contributions from relatives which are not in reality received by the needy individual..$^{128}$

Because the Dawson v. Myers ${ }^{129}$ court was correct in its observation that the HHS subsection 401(c) regulation, so hotly contested in these cases, ${ }^{130}$ pertains to general eligibility requirements and not directly to financial eligibility requirements, ${ }^{131}$ it becomes important to examine the regulation dealing directly with medically needy financial eligibility. ${ }^{132}$ That regulation establishes that a state agency determining Medicaid eligibility must, "[f]or aged, blind, or disabled individuals in States covering all SSI recipients, deduct the value of resources that would be deducted in determining eligibility under SSI." 133

The resources to be deducted in determining SSI eligibility may be found in another set of HHS regulations. ${ }^{134}$ Excludable resources include an applicant's home, household goods, automobile, property essential to self support, and life insurance up to a face value of $\$ 1,500.135$ Under the statute and regulations in effect when

127 See note 68 supra.

128 S. REP. No. 404, 89th Cong., 1st Sess. 78, reprinted in [1965] U.S. ConE Cong. \& AD. News 1943, 2018.

129622 F.2d 1304.

13042 C.F.R. $\$ 435.401$ (c) (1979). See note 64 supra.

131 See text accompanying notes $82 \& 83$ supra.

13242 C.F.R. $\$ 435.845$ (1979); 45 Fed. Reg. 24,886 (1980) (to be codified in 42 C.F.R. $\$ 435.845(\mathrm{e}))$.

13342 C.F.R. $\$ 435.845$ (d) (1979) (emphasis added). States have an option, under 42 U.S.C. $\$ 1396 \mathrm{a}(\mathrm{f})$ (1976), to use requirements more restrictive than SSI in their Medicaid programs. States choosing this option are the so-called "209(b)" states. See notes 25 \& 43 supra. For an explanation why the reasoning in cases like Fabula v. Buck, 598 F.2d 869 (4th Cir. 1979), and Caldwell, 621 F.2d 491, is not applicable to 209(b) states, see Drogolewicz v. Quern, 74 Ill. App. 3d 862, 867, 393 N.E.2d 1212, 1216-17 (1979).

13420 C.F.R. $\$ \$ 416.1210 .1237$ (1980).

135 Id. 
Dawson was decided, ${ }^{138}$ resources that exceeded these limitations could be disposed of prior to application for benefits without any effect on SSI eligibility. ${ }^{137}$ Excess resources held by the SSI applicant at the time of application, however, could not be disregarded in determining the eligibility of an SSI applicant. ${ }^{138}$

A reasonable resolution of the asset transfer issue, therefore, would be the invalidation ${ }^{139}$ of a state's asset transfer rule only to the extent that it applies to assets, such as a home or car, that would have been deducted in determining eligibility for SSI benefits. This interpretation would reverse the results reached by the courts in both Dawson and Caldwell v. Blum. It would also prevent the transfer of assets, such as valuable commercial property, ${ }^{140}$ that can reasonably be expected to help defray the cost of medical care. At the same time, this interpretation allows the states to provide benefits to truly needy applicants who, voluntarily ${ }^{141}$ or through fraudulent inducement, ${ }^{142}$ transfer more personal assets.

In view of the legislative history of the comparability provision, ${ }^{143}$ it is uncertain whether Congress intended even this degree of comparability between SSI and Medicaid recipients. Congress has entrusted the administration of the Medicaid program to HHS, however, and in the absence of clear indications that the HHS regulations misconstrued the statute, they should stand..$^{144}$

136 Congress has since amended the law to restrict asset transfers by SSI applicants. Social Security Amendments of 1980, Pub. L. No. 96-611, $\$ 5$ (a), 94 Stat. 3567 (to be codified in 42 U.S.C. $\$ 1382 \mathrm{~b}$ ). See text accompanying notes $147-49$ infra.

137 Soctad Securtix Clatms Manuat, supra note 28, at $\$ 12507$ (a). See text accompanying notes $25-29$ supra.

138 Owners of excess resources who did not dispose of them prior to application could still receive benefits. The recipient had to agree in writing to dispose of the excess assets, however, and the payments received during the period of disposal were considered "overpayments." 20 C.F.R. $\$ 416.1240$ (1980). In addition, if an SSI recipient sold an asset that was deducted in determining eligibility, the proceeds of the sale could be included in his resources. Social Securrty Clanss MaNOAI, supra note 28 , at $\$ 12508$ (a) (2).

139 The legislation permitting states to impose asset transfer rules is not retroactive. See Social Security Amendments of 1980, Pub. L. No. 96-611, §5(b), 94 Stat. 3567 (to be codified in 42 U.S.C. $\$ 1396 a$ ).

140 See text accompanying notes 108-10 supra. All of the plaintiffs in Fabula, 598 F.2d 869, transferred assets that were or would have been excluded in their eligibility determinations. The Fabula court stated specifically that this distinction did not affect its decision. Id. 872 n.6. Under the regulations examined in this Comment, however, the distinction is not an irrelevant one.

141 See, e.g., text accompanying note 107 supra.

142 See, e.g., text accompanying notes 102-06 supra.

143 See note 68 supra.

144 See New York Dep't of Social Servs. v. Dublino, 413 U.S. 405, 421 (1973) (quoting Red Lion Broadcasting Co. v. FCC, 395 U.S. 367, 381 (1969)) ("[T]he 


\section{The Legislative Nonsolution}

Medically indigent elderly individuals, if defined to include all those who may freely transfer their assets in order to obtain government subsidization of long-term care, are a potentially huge number of people. ${ }^{145}$ Congress recently accommodated the states' concern with preventing abuse of the Medicaid program by authorizing delays in Medicaid eligibility for applicants who transfer assets. 340 Congress failed, however, to outline rules that would also provide necessary medical care to the needy.

The Social Security Amendments of 1980, which became effective on March $1,1981,{ }^{147}$ provide that any asset given away or sold for less than fair market value within twenty-four months prior to application for benefits will be included in the applicant's resources if the asset was disposed of for the purpose of establishing eligibility for SSI. ${ }^{148}$ The amount included will be the asset's fair market value at the time it was transferred, less any compensation received. "Convincing" evidence that the transfer was made "exclusively" for some other purpose is required to rebut a statutory presumption that the transfer was made to establish eligibility for SSI benefits. ${ }^{148}$

States now are also expressly authorized to deny Medicaid to an applicant who "would not be eligible for such medical assistance but for the fact that he disposed of resources for less than fair market value." 150 State procedures for determining Medicaid eligibility still may be no more restrictive than the federally mandated SSI procedure, with one exception: if the uncompensated value ${ }^{151}$ of the asset transferred by an applicant is greater than $\$ 12,000$, states may delay eligibility for longer than twenty-four months. In such cases, the period of ineligibility must "bear a reasonable relationship" to the uncompensated value of the asset transferred.182

construction of a statute by those charged with its execution should be followed unless there are compelling indications that it is wrong. . . .").

145 See text accompanying notes 32,33 \& 35-37 supra.

146 Social Security Amendments of 1980, Pub. L. No. 96-611, $\$ 5,94$ Stat. 3567 ( to be codified in 42 U.S.C. $\$ \$ 1382 b, 1396 a$ ).

147 The law provided that the SSI amendment was to become effective with respect to applications filed "on or after the first day of the first month which begins at least 60 days after the date of enactment of this Act." Id. $\$ 5(\mathrm{c})$.

148 Id. $\$ 5$ (a).

$140 \mathrm{Id}$.

150 Id. $\$ 5(\mathrm{~b})$.

151 The fair market value of the asset at the time of transfer, less any compensation received. Id. $\S 5(\mathrm{a})$.

$162 I d . \$ 5(\mathrm{~b})$. 
Finally, if an applicant is ineligible for Medicaid solely because of the SSI rule, ${ }^{153}$ but would be eligible under the state's asset transfer rule, the state may apply its own rule in lieu of the SSI rule. ${ }^{154}$

Unfortunately, Congress did not establish more specific guidelines for states to follow in creating their asset transfer rules. The asset transfer cases illustrate the deficiencies of already existing state rules; ${ }^{155}$ Congress should have scrutinized these cases more carefully and dealt with at least the most glaring problems. Thoughtful construction of asset transfer rules at the state level, however, can cure some of the congressional omissions. ${ }^{156}$

The new legislation does not establish a minimum dollar value for the asset transfers that will preclude eligibility for Medicaid benefits. Such a provision would have prevented states from penalizing individuals who transfer minimal resources. ${ }^{\mathbf{1 5 7}}$ More importantly, however, the legislation fails to address the problem of an interminable eligibility delay. ${ }^{158}$ For asset transfers whose uncompensated value exceeds $\$ 12,000$, the legislation places no limit on the period of time during which states may delay eligibility. It merely demands that a period of ineligibility exceeding twentyfour months "bear a reasonable relationship" to the uncompensated value of the asset transferred.159 This loose standard creates a risk that the length of eligibility delay will be measured against a state's limited reimbursement rates rather than against the applicant's medical care needs, ${ }^{160}$ leading to inhumane delays. The provision

153 SSI recipients are categorically needy and therefore automatically eligible for Medicaid in states using SSI eligibility criteria. See note 25 supra \& accompanying text. If an SSI applicant is declared ineligible for SSI, he can qualify for Medicaid only if he is medically needy.

${ }_{154}$ Social Security Amendments of 1980, Pub. L. No. 96-611, $\$ 5(b), 94$ Stat. 3567 (to be codified in 42 U.S.C. $\$ 1396 a$ ).

155 See notes 99-111 supra \& accompanying text.

156 Any restrictions established should avoid the punish-the-victim philosophy that has characterized some efforts to control widespread provider abuse, see $M$. Mendelson, Tender Loving Greed (1974), by cutting back on benefits to recipients. An example of such a cutback is discussed in Budnicki v. Beal, $450 \mathrm{~F}$. Supp. 546 (E.D. Pa. 1978) (Pennsylvania attempted to control widespread fraud and abuse by providers of orthopedic shoes by discontinuing its orthopedic shoe program rather than by prosecuting unscrupulous providers.).

157 See H.R. Rep. No. 1167, 96th Cong., 2d Sess. 84 (1980). Cf. Pa. Stat. ANN. tit. 62, $\$ 441.2$ (Purdon Supp. 1980-81) (denying medical assistance to an individual who transfers assets worth $\$ 500$ or more without fair consideration). 158 This problem was highlighted by Buckner v. Maher, 424 F. Supp. 366 (D. Conn. 1976), aff'd, 434 U.S. 898 (1977). See text accompanying notes 102-07 supra.

159 Social Security Amendments of 1980, Pub. L. No. 96-611, $\$ 5(b), 94$ Stat. 3567 ( to be codified in 42 U.S.C. $\$ 1396 \mathrm{a}$ ).

160 See, e.g., Buckner, 424 F. Supp. at 370 \& n.8 (Connecticut statute required applicant to "work off" the value of the asset transferred according to a standard 
reflects a lack of consideration of the actual costs of long-term care, which may run as high as $\$ 20,000$ per year. ${ }^{161}$ An individual who transfers assets with an uncompensated value of $\$ 14,000$ and consumes care costing $\$ 20,000$ per year thus could be denied benefits for a period of time much longer than that for which his or her transferred assets would have paid. Such a practice would be both illogical and punitive.

Because the legislation gives states some flexibility to fashion asset transfer policies, ${ }^{162}$ states can cure this defect by making the length of eligibility delay proportionate to the dollar value of the assets transferred and the actual costs of the care provided. Under such a rule, a person who transfers assets with an uncompensated value of $\$ 14,000$ and consumes health care costing $\$ 20,000$ per year would be denied benefits for only about eight and one-half months, by which time his assets would have been exhausted anyway. ${ }^{103}$

Another flaw in the legislation is the vague standard of "convincing evidence" that must ${ }^{164}$ be met to rebut the presumption that the transfer was made to establish eligibility for Medicaid benefits. Whether this standard requires the use of only "objective" factors, such as those required by the California regulations, ${ }^{165}$ or whether it permits subjective factors, such as intent or lack of knowl-

state formula rather than according to the applicant's needs). Cf. 22 CAL. AD. Cone $\$ 50411$, quoted in Brief for Appellees at 14 n.5, Dawson v. Myers, 622 F.2d 1304 (9th Cir.), cert. granted sub nom. Beltran v. Myers, 101 S. Ct. 353 (1980) (" "period of ineligibility may be further reduced by deducting the actual cost to the applicant or beneficiary for medical expenses incurred" ").

161 Brief on Behalf of Appellant at 25, Caldwell v. Blum, 621 F.2d 491 (2d Cir.), petition for cert. filed, 49 U.S.L.W. 3005 (U.S. June 24,1980 ) (No. 79-2034).

162 "In the case of medicaid eligibility, the amendment makes explicit the intent . . . to grant the States more flexibility. The amendment would permit States to establish disposal of asset disqualification rules for medicaid purposes which differ in detail from the SSI rule." 126 CoNG. REc. S16,505-06 (daily ed. Dec. 13, 1980) (remarks of Sen. Long).

163 This proposal establishes a more realistic link between the value of the assets transferred and the cost of care consumed. It permits regional variations in the length of eligibility delay. In states where long-term care is relatively less expensive, therefore, the delay could be longer.

164 SSI applicants also must rebut a statutory presumption of forbidden purpose by proving that the transfer was "exclusively" for some other purpose. Social Security Amendments of 1980, Pub. L. No. 96-611, $\$ 5(\mathrm{a}), 94$ Stat. 3567 (to be codified in 42 U.S.C. $\$ 1382 \mathrm{~b})$. The law provides that state procedures for determining Medicaid eligibility may be no more restrictive than the SSI procedure (with one exception, see text accompanying notes $151-52$ supra). Id. $\$ 5(\mathrm{~b})$. Presumably, states are free to use a less stringent evidentiary standard, but it is difficult to identify a less stringent standard because the SSI standard is so poorly defined.

105 See note 48 supra. 
edge, to be introduced in rebuttal is unclear. If the concern of the states is to prevent fraud and abuse, subjective factors should be considered relevant. Subjective factors are particularly important for individuals who are incapable of making rational decisions concerning the disposition of their property, or who are powerless to stop the disposition of property in which they have an interest. ${ }^{166}$

Creating an automatic exemption from the presumption of forbidden purpose when an applicant transfers assets excluded from the eligibility determination could also cure the statute's vague evidentiary standard. ${ }^{167}$ The states probably will be reluctant to choose this method, however, because one goal of state asset transfer rules is to keep even excludable resources in the Medicaid recipient's possession so that the state may recover the cost of benefits out of those resources after the recipient dies. ${ }^{168}$ To discourage asset transfers by Medicaid recipients and to provide a source from which to recover expenditures, therefore, states may wish to make it difficult for an applicant to rebut the presumption of forbidden purpose, even when otherwise excludable resources are transferred. If Congress wished to recognize this state interest in recovering expenditures, it should have done so explicitly. Both the states and their Medicaid applicants then would have notice that such restrictions on asset transfers are consistent with federal law.

Similarly, Congress should have made clear whether a state's presumption of forbidden purpose conflicts with federal law. A reasonable interpretation of the new SSI rule concerning asset transfers ${ }^{169}$ is that a transfer of excludable resources ${ }^{170}$ cannot give rise to the presumption of purpose to qualify for benefits because, by definition, excludable resources do not affect eligibility. If HHS chooses this interpretation to implement the statute, but states choose to presume that any transfer of assets is made in order to establish eligibility, then more litigation over the still unresolved issue of "comparability" between SSI and Medicaid beneficiaries ${ }^{171}$ is likely to arise. Hence, this deficiency in the legislation may result in delay or denial of benefits to elderly medically indigent individuals having neither the time nor the money for protracted litigation.

166 See text accompanying notes $2-4$ supra.

167 For example, an applicant's home or car could be excluded. See 20 C.F.R. $\$ \$ 416.1210-.1237$ (1980).

168 See, e.g., N.Y. Soc. SERv. LAw $\$ 366$ (1)(e) (McKinney Supp. 1980-81).

169 See text accompanying notes $147-49$ supra.

170 See text accompanying note 135 supra.

171 See note 62 supra \& accompanying text. 
Other legislation introduced to, but not enacted by, the 96 th Congress would have authorized states to recover the cost of benefits from a transferee up to the uncompensated value of the property he or she has received. ${ }^{172}$ The legislative history accompanying that provision, explicitly recognizing the possibility that elderly individuals may be victimized by those to whom they transfer resources, ${ }^{173}$ declared that states should not "penalize individuals that have been subject to such exploitation by delaying their eligibility for medicaid." 174 States should remember this possibility of exploitation when they write their transfer of assets rules. They also should keep in mind individuals, such as Mr. Manahan,, ${ }^{175}$ who lack any real control over the distribution of assets in which they may have a legal interest. State rules should give limited discretion to appropriate social services officials to reduce or waive eligibility delay ${ }^{176}$ when a delay would unreasonably or unfairly deny needed Medicaid benefits.

Finally, states will have to supply certain procedural details omitted from the federal statute in order to have a workable plan. ${ }^{177}$ A forum must be established to hear evidence concerning the purpose of the applicant's transfer of assets. There must also be a

172 H.R. 7765, 96th Cong., 2d Sess. $\$ 333(\mathrm{a})(2)$ (1980). The legislative history accompanying the provision indicates an intent that states would use "appropriate State judicial procedures to assure due process to a transferee." H.R. REP. No. 1167, 96th Cong., 2d Sess. 85 (1980). No actions for recovery could have been initiated later than three years after the end of the transferor's ineligibility period. The amount of recovery would have been limited by the "lesser of the uncompensated value [of the transferred asset] or the cost of the medical assistance provided to the transferor during or after the period the transferor was (or could have been) determined to be ineligible." Id.

Such safeguards may not eliminate all potential constitutional objections by transferees if states do attempt to recover from them. However, such a recovery could be considered analogous to the federal estate tax imposed on gifts made in contemplation of death. See I.R.C. $\$ 2035$.

173 H.R. Rep. No. 1167, 96th Cong., 2d Sess. 85 (1980). This sort of victimization of the elderly has been recognized by the courts as well. In Moran $v$. Lascaris, the court discussed the sale of an elderly woman's home by her son while she was in a nursing home. 61 A.D.2d 405, 402 N.Y.S.2d 486 (1978). There was no evidence that she was aware of her son's action, but the sale resulted in the termination of the woman's Medicaid benefits by the state agency. The court reversed the termination.

174 H.R. Rep. No. 1167, 96th Cong., 2d Sess. 85 (1980).

175 See text accompanying notes 2-4 supra.

176 See H.R. 7765, 96th Cong., 2d Sess. $\$ 333(\mathrm{a})(2)$ (1980), which would have permitted states to reduce or waive a period of ineligibility if such action was "justified."

177 State procedures for determining Medicaid eligibility can be no more restrictive than SSI procedures. Social Security Amendments of 1980, Pub. L. No. 96-611, $\$ 5$ (b), 94 Stat. 3567 (to be codified in 42 U.S.C. $\$ 1396 a$ ). State procedures, therefore, will have to comply with whatever regulations HHS promulgates to implement the statute. 
mechanism for administrative appeal and/or judicial review in the event an application is denied. Whatever procedures are established must be efficient and expeditious. Time is of the essence because the elderly applicant often will have little time to wait.

\section{Conclusion}

Many elderly people require long-term institutional care today and will continue to require such care in the future. This care often replaces home living and becomes a permanent arrangement. Forbidding all asset transfer rules could gradually convert the Medicaid program, designed to provide health care to the poor, into a long-term care subsidy for persons with moderate or substantial assets. Such a result could encourage states to terminate assistance to the medically needy altogether.

This Comment has analyzed recent cases dealing with transfer of assets rules, proposing an alternative resolution that strikes a fairer balance between the interests of the states and the needs of individuals. It also has examined and criticized recent legislation that permits states to impose asset transfer rules, suggesting elements that states should incorporate in their rules to assure that Medicaid abuse may be prevented, without destroying the original congressional objective of providing medical assistance to the needy.

[NotE: After this Comment had gone to press, the Supreme Court handed down its decision in Beltran v. Myers, 49 U.S.L.W. 4534 (U.S. May 18, 1981). The Court vacated the decision of the Ninth Circuit and remanded the case for reconsideration in light of the legislation discussed in this Comment.] 